\title{
Analisis Teori Karir Krumboltz: Literature Review
}

\author{
Azmatul Khairiah Sari ${ }^{{ }^{*}}$, A. Muri Yusuf ${ }^{2}$, Megaiswari ${ }^{3}$, Afdhal $^{4}$ \\ ${ }^{1234}$ Universitas Negeri Padang \\ *Corresponding author, e-mail: azmatulkhairiah998@gmail.com
}

Received January 12th , 2021; Revised Month February 1st, 2021;

Accepted March 15, 2021; Published Online March 20, 2021

\section{Conflict of Interest} Disclosures:

The authors declare that they have no significant competing financial, professional or personal interests that might have influenced the performance or presentation of the work described in this manuscript.

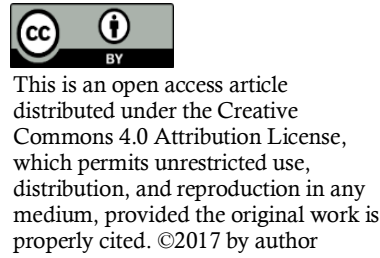

properly cited. C2017 by author

\begin{abstract}
Students must plan and orientate their career direction from an early age. This is done so that the individual knows where the future career is going and what he must do to achieve the planned career. Choosing a major, choosing extracurricular activities that support the direction of career choices also need to be done. School is a place that plays a role in the direction of student career planning. Besides that, parents also make a significant contribution to the direction of student career planning. There are many career development theories that can be used by counseling teachers or counselors in providing career counseling services. One of them is Krumboltz's social theory of learning. Krumboltz theory contributes quite a lot in the direction of career planning for students in schools or employees who will choose a job. Then we will try to review how Krumboltz's theory sees the direction of student career planning.
\end{abstract}

Keywords: Krumboltz Theory, Career Counseling Guidance

Indonesian Abstract: Individu harus merencanakan dan mengorientasikan kemana arah karirnya sejak dini. Hal ini dilakukan agar individu mengetahui kemana arah karir masa depan dan apa yang harus ia lakukan untuk mencapai karir yang direncanakan tersebut. Memilih jurusan, memilih kegiatan ektrakurikuler yang mendukung arah plihan karir juga perlu dilakukan. Sekolah menjadi wadah yang cukup berperan pada arah perencanaan karir siswa. Disamping itu orangtua juga memberikan kontribusi yang cukup signifikan pada arah perencanaan karir siswa. Banyak teori pengembangan karir yang bisa digunakan oleh guru bimbingan konseling atau konselor dalam memberikan layanan konseling karir. Salah satunya adalah teori sosial belajar Krumboltz. Teori Krumboltz cukup banyak memberikan kontribusi dalam arah perencanaan karir siswa di sekolah ataupun karyawan yang akan memilih pekerjaan. Maka kita akan mencoba mengulas bagaimana teori Krumboltz melihat bagaimana arah perencanaan karir siswa.

Kata kunci: Teori Krumboltz , Bimbingan Konseling Karir

How to Cite: Azmatul Khairiah Sari, A. Muri Yusuf, Megaiswari, Afdhal.2021. Analisi Teori Karir Krumboltz: Literature Review. JIBK Undiksha, 12 (1): pp. 107-112, DOI: http://dx.doi.org/10.23887/xxxx 


\section{Pendahuluan}

Bimbingan dan konseling merupakan pendidikan. Karena adanya kegiatan pembelajaran yang diberikan guru bimbingan konseling kepada siswa. Bimbingan dan konseling disesuaikan dengan tujuan pendidikan. Dalam pendidikan memenfaatkan banyak faktor untuk mencapai keberhasilan sebuah pendidikan (Khairun, $\mathrm{dkk}, 2016)$. Tujuan pendidikan sama dengan tujuan pelaksanaan bimbingan konseling. Dengan pendidikan diharapkan adanya perubahan pada siswa yang dididik (Defriyanto, dkk, 2016). Perubahan yang diharapkan yaitu siswa dapat mengembangkan potensinya. Yaitu pengembangan potensi siswa secara maksimal sehingga bisa mencapai kemandirian diri yang sempurna.

Pengembangan potensi siswa bisa dilakukan melalui bimbingan konseling. Dimana bimbingan konseling juga merupakan proses pendidikan. Bimbingan konseling membantu pengembangan potensi secara maksimal. Pengembangan diri pada bidang pribadi, sosial belajar, karir, keluarga dan agama. Pengembangan potensi pada bidang karir dapat terlihat dari siswa sudah bisa merencanakan arah karir. Dan individu merencanakan arah karirnya sesuai dengan tahap perkembangan. Pada masing-masing tugas perkembangan, seorang individu juga menguasai tugas perkembangan

Dalam memilih dan menjalankan sebuah karir, individu memiliki perkembangan karir sepanjang rentan kehidupannya. Perkembangan karir akan mengarahkan pada aktualisasi diri (Annisa, dkk, 2016). Pada masa anak-anak, seorang individu akan berada pada masa Question age, dimana ia akan selalu bertanya (Jannah, 2015). Untuk tugas perkembangan karir, anak-anak akan menanyakan berbagai hal yang berkaitan dengan profesi tertentu. Apa itu guru, apa itu dokter, dan profesi lainnya. Kemudian dari pertanyaan yang diajukan maka ia akan membentuk persepsi tertentu mengenai profesi tersebut. Anak akan membantuk suatu konsep tersendiri mengenai profesi. Setelah itu pada masa tingkat SMP, anak akan membentuk arah perencanaan karir dan pada tingkat SMA anak akan mengambil jurusan sesuai dengan arah minat karir yang ia inginkan. Pada perguruan tinggi ia akan memilih jurusan yang akan mengarah pada keputusan karirnya.

Sebagai siswa, ia akan memiliki pandangan atau persepsi yang berbeda dengan tujuan karirnya. Pada akhirnya siswa mewujudkannya akan berbeda-beda (Mardiyati, dkk, 2015). Siswa juga diharapkan dapat menguasai kemampuan dan kompetensi baik dalam bidang pribadi, sosial, belajar dan karirnya (Sumita, dkk, 2018) jadi seorang siswa akan mengupayakan pengembangan potensi di bidang karir.

Untuk itu dalam perkembangan karir, akan ada beberapa faktor yang mempengaruhi arah perencanaan karir. Ada beberapa teori yang menjelaskan mengenai arah perencanaan karir siswa. Salah satunya adalah teori karir Krumboltz. Teori Krumboltz menjadi teori yang cukup urgen dalam pengembangan karir atau perencanaan arah karir siswa. Siswa memilih arah perencanaan karirnya mengarah pada beberapa faktor. Siswa ada yang sudah bisa merencanakan sendiri arah pilihan karirnya, ada yang masih ragu dan ada yang sudah mantap dengan arah perencanaan karinya.

Keraguan, ketidakpastian dan bagaimana seorang siswa dalam membuat perencanaan arah karirnya dipengaruhi oleh beberapa faktor. Dan faktor tersebut diantaranya seperti lingkungan dan pribadinya (Sastrawati, dkk, 2018) teori Krumboltz menyatakan bahwa seorang siswa akan merencanakan pilihan karir karena adanya lingkungan sekitar yang membentuk persepsi mengenai suatu pekerjaan. Bisa jadi faktor dari diri sendiri yang melihat atau menyukai pekerjaan tertentu.

Krumboltz menyatakan ada empat kategori faktor yang mempengaruhi pengambilan keputusan karir yaitu faktor genetik, lingkungan, belajar, dan keterampilan menghadapi tugas atau masalah. Menurut teori belajar, dalam pengambilan keputusan karir orang berada di lingkungan tertentu, dengan membawa ciri-ciri bawaan dari keturunannya dan menghadapi berbagai pengalaman belajar (Warsita, 2018). Jadi teori Krumboltz memiliki teori bahwa dalam perencanaan arah karir siswa, individu akan dipengaruhi oleh empat faktor tersebut. Empat faktor ini akan saling bersinergi dalam memberikan arahan dalam perencanaan arah karir seorang individu.

\section{Metode}

Metode dalam proses penulisan artikel ini yaitu literature review. Pencarian literature baik internasional maupun nasional yang dilakukan dengan menggunakan database EBSCO, ScienDirect, Proquest, ISJD, Scoolar, Garuda Ristekbrin, dan lain - lain. Pada tahap awal pencarian artikel jurnal diperoleh lebih dari 10 artikel dari tahun 2001 sampai tahun 2019 dengan menggunakan kata kunci "teori karir krumboltz" yang diindentifikasi tetapi belum dieksplorasi relevansi dengan berbagai artikel untuk dikompilasi. Dari jumlah diatas hanya sekitar 3 artikel yang dianggap sesuai. 


\section{Hasil dan Pembahasan}

Karir adalah sesuatu yang sangat urgen dalam kehidupan seorang individu. Karir diciptakan dan dikembangkan oleh individu sepanjang rentang kehidupannya. Bahkan ketika seorang individu berada pada masa anak usia dini dia sudah mulai mengeksplorasi jenis-jenis profesi yang mungkin ia bisa masuki. Walaupun anak-anak usia dini belum menjadikan ini sebagai keputusan dalam berkarir.

Karir membutuhkan pengelolaan diri yang baik dari individu tersebut, memahami orang lain dan lingkungan, serta berhubungan dengan orang lain dan lingkungan. Kecerdasan dan keahlian juga menjadi point penting untuk mencapai keberhasilan dalam berkarir. Namun perlu digarisbawahi kecerdasan dan keahlian saja belum memadai.

Karir diartikan sebagai urutan posisi atau pekerjaan utama yang diduduki seseorang sejak remaja sampai pensiun selama rentang kehidupan (Yusuf, 2002: 29). Apabila seorang individu dapat menduduki sebuah posisi yang bagus di sebuah lembaga atau instansi, maka bagi masyarakat akan mengatakan bahwa ia berhasil dalam karir.Winkel (2007) menyatakan bahwa karir adalah pekerjaan atau jabatan yang ditekuni dan diyakini sebagai panggilan hidup yang meresapi seluruh alam pikiran dan perasaan seseorang serta mewarnai gaya hidupnya.

Abdullah (2018) karier merupakan suatu proses kemajuan dari rangkaian-rangkaian perjalanan pengembangan pengalaman seseorang sepanjang waktu yang dilaluinya dan ini berkaitan dengan pekerjaan utamanya. Karir akan melekat pada gaya hidup dan perasaan seseorang sehingga ia akan sungguh menggap bahwa karir sebagai suatu kebutuhan dalam dirinya.

Karir yang dipilih nanti akan menjadi tempat yang subur bagi seorang individu untuk beraktualisasi (Aminurrohim, dkk, 2014). Jadi dengan adanya karir maka seorang individu akan beraktualisasi di lingkungannya tersebut. Dengan berkarir individu bisa menampakkan eksistensi dirinya di lingkungan sekitarnya.

Karena teori mengenai karir dianggap penting, maka banyak para ahli yang mengemukakan mengenai teori perkembangan karir. Salah satunya adalah Krumboltz. Teori pembelajaran sosial Krumboltz membahas bagaimana individu kognisi dan pengalaman belajar mempengaruhi pengambilan keputusan karir (Mitchell dan Krumboltz 1996). Selain itu teori ini menjelaskan bagaimana pendekatan seseorang terhadap tugas pembelajaran, penetapan tujuan, klarifikasi nilai, menghasilkan pilihan karir dan memperoleh informasi pekerjaan tergantung pada interaksi antara genetik, lingkungan sosial dan budaya, dan masa lalu pengalaman belajar.

Teori Krumboltz ini memberikan pandangan bagi klien bahwa genetik, lingkungan dan pengalaman belajar bisa mempengaruhi perencanaan karir dan pengambilan keputusan karir. Dari pengalaman dan pengetahuan mengenai suatu profesi maka seorang individu merencanakan arah pilihan karir tersebut.

Dalam teori Krumboltz, proses perkembangan karier melibatkan empat faktor yaitu: Warisan genetik dan kemampuan khusus, Kondisi dan peristiwa lingkungan, pengalaman belajar, dan keterampilan pendekatan tugas (Zunker, 2006). Jadi menurut Krumboltz, karir yang direncanakan oleh seorang individu akan dipengaruhi oleh empat faktor. Empat faktor inilah nantinya yang akan saling bersinergi dalam membentuk sebuah arah perencanaan karir bagi seorang individu dan pada akhirnya ia memutuskan karir apa yang akan ia lalui.

Yang pertama, warisan genetik dan kemampuan khusus mencakup sejumlah kualitas bawaan yang dapat meningkatkan kesempatan karier individu. Masing-masing individu lahir dengan potensi bawaan dari lahir. Potensi tersebut berupa bakat, minat dan keterampilan khusus yang dimiliki individu tersebut. Yang harus difahami bahwa potensi dan keterampilan khusus tersebut harus bisa dikembangkan dengan baik oleh indiviodu tersebut.

Tidak mengherankan apabila ada seorang individu yang memiliki kemampuan khusu sama seperti yang dimiliki oleh orangtuanya. Hal ini disebabkan faktor warisan genetik yang diturunkan dari orangtuanya tersebut. Ketika kita melihat ayahnya pintar dalam public speaking dan anaknya juga memiliki kemampuan yang sama, maka secara langsung kita akan mengartikan ini adalah warisan genetik dari orangtuanya. Potensi dari warisan genetik inilah yang akan menjadi dasar bagi seorang individu dalam merencanakan arah pilihan karirnya. 
Faktor kedua, kondisi dan peristiwa lingkungan merupakan hal dari luar dari individu yang bisa mempengaruhi seorang individu dalam merencanakan arah karirnya. Faktor lingkungan bisa berupa kesempatan bekerja, memiliki kesempatan dalam pendidikan, dan hal-hal yang berada di luar individu dan bisa mempengaruhi bagaimana karir tersebut.

Tidak semua individu bisa memiliki kesempatan dalam menempuh bangku perkuliahan, tidak semua individu yang memiliki kesempatan mendapatkan beasiswa, dan banyak faktor lingkungan lainnya yang tidak mendukung potensi dasar seorang individu dari warisan genetik orangtuanya. Jika warisan genetik yang diturunkan oleh orangtua kemudian didukung dengan lingkungan yang memberikan kesempatan kepada individu tersebut mengasah kemampuan khusus yang ia miliki, tentu akan membuat faktor pertama dan kedua yang disampaikan oleh Krumboltz akan menjadi kuat.

Faktor ketiga, pengalaman belajar. Pengalaman belajar adalah hal yang dapat diambil oleh peserta didik setelah melaksanakan pembelajaran. Dengan adanya pengalaman belajar inilah individu akan bisa memahami sebuah karir dan memaknainya sehingga membentuk arah perencanaan karir. Dengan pengalaman belajar tersebut individu bisa memiliki perspektif yang bagus mengenai sebuah profesi dan menjadikannya sebagai perencanaan arah karirnya.

Pengalaman belajar yang didapatkan oleh individu selama rentang kehidupannya akan membuat faktor pertama, kedua dan ketiga akan menjadi kuat, apabila pengalaman belajar yang ia dapatkan adalah sesuatu yang bermakna. Bermakna dan bernilai positif tentu akan membuat potensi yang menjadi dasar dalam perencanaan karir dan lingkungan yang memberikan kesempatan untuk mengembangkan potensi tersebut, sehingga ia semakin memiliki tekad yang bulat untuk merencanakan arah pilihan karir. Apabila individu memiliki pengalaman belajar yang tidak menyenangkan atau negatif mengenai suatu profesi maka hal ini akan menyebabkan faktor warisan genetik dan lingkungan tidak bersinergi dengan pengalaman belajar yang ia miliki.

Faktor keempat, keterampilan pendekatan tugas (tasks approach skills), mencakup perpaduan antara warisan genetik, kondisi lingkungan dan pengalaman belajar. Dengan kemampuan menyelesaikan tugas maka ia akan bisa menyelesaikan masalah yang ia hadapi, bagaimana ia bisa membangun sebuah komunikasi dengan orang sekitar dan banyak lagi keterampilan lainnya.

Pada faktor keempat, inidvidu harus memehami bahwa dalam perjalanan karir akan menemui banyak rintangan dan hambatan. Ketika individu merasa menyerah dengan kondisi yang tidak mendukungnya untuk merencanakan arah karir, maka karir tidak akan berkembang dengan baik. Sebagai contoh, individu yang memiliki keterampilan khusus dalam bidang seni, kemudian diarahkan pada sekolah jurusan seni dan ia memiliki pengalaman belajar yang positif mengenai seni. Ketika ia merencanakan arah karirnya, mengalami hambatan dimana kesempatan bekerja pada jurusan seni hanya ada diluar kota dan orangtua tidak mau berpisah dengan anaknya. Tentu individu harus bisa menyelesaikan masalah yang bisa menghambat perkembangan karirnya. Kemampuan dalam menyelesaikan masalah inilah yang diperlukan dalam sebuah karir menurut Krumboltz.

Teori Krumboltz tidak melihat karir seorang indivdiu secara sempit namun ia melihat bahwa individu akan memiliki faktor dalam perencanaan dan pengambilan keputusan karirnya. Menurut Bandura yang juga merupakan tokoh dalam aliran behavioral, perilaku seseorang dijelaskan dalam bentuk atau keadaan timbal balik interaksi antara penentu pribadi (yang termasuk faktor kognitif dan faktor pribadi), perilaku, dan lingkungan, yang dikenal sebagai triadic reciprocality (Fadilla, dkk, 2019). Dalam hal ini, bahwa dalam perencanaan karir atau pengambilan keputusan karir dipengaruhi oleh internal yaitu pribadinya dan ekternal yaitu lingkungan. Faktor internal yang terdiri dari bakat, minat, potensi dan hal yang yang menyangkut pada diri individu yang memberikan kontribusi yang signifikan dalam arah perencanaan karir atau keputusan karir seorang individu.

Berminat pada olahraga maka cenderung akan mengambil jurusan olahraga dan merencanakan akan menjadi atlet untuk kedepannya. Memiliki ketertarikan pada proses pembelajaran dari guru dan merencanakan akan menjadi seorang guru kedepannya. Ini adalah faktor internal yang terdapat dalam diri individu.

Selain faktor internal, seorang individu akan mendapatkan pengaruh dari faktor lingkungan. Baik itu kesempatan belajar, kesempatan beasiswa, dukungan orangtua dan sebagainya. Karena menurut teori ini 
adalah hal yang mustahil bagi sebuah karir apabila internal dan eksternal tidak saling mendukung dalam perencanaan arah karirnya.

Maka dari itu, individu yang memiliki masalah mengenai hal yang berkaitan dengan arah perencanaan karir atau keputusan karirnya bisa memanfaatkan layanan bimbingan konseling. Dalam layanan bimbingan konseling akan diarahkan individu untuk memanfaatkan empat faktor yang sesuai dengan konsep dari Krumboltz tersebut.

Ada beberapa hal yang menjadi pertimbangan mengapa bimbingan konseling mengenai karir diperlukan. Diantaranya adalah (1) individu perlu mengembangkan dirinya sehingga konselor akan emndirong kliennya untuk menelusuri apa yang menjadi hal potensial bagi dirinya utnuk merencanakan atau mengambil keputusan tentang karir (2) Konselor perlu membantu klien mempersiapkan perubahan dalam tugas dan kondisi kerja (3) klien memerlukan konselor sehingga ia diberdayakan untuk melakukan sebuah tindakan mengenai arah perencanaan dan pengambilan keputusan mengenai karirnya (Mitchell and Krumboltz 1996, Mitchell, Jones and Krumboltz 1979).

Layanan bimbimngan konseling dalam bidang karir dapat diberikan oleh konselor untuk memgarahkan arah perencanaan karir atau pengambilan keputusan karirnya. Dengan layanan bimbingan konseling yang sesuai akan menyebabkan klien merencanakan arah pilihan karirnya dengan tepat. Salah satu layanan yang bisa diberikan adalah layanan konseling individual. Maka klien dan konselor bisa mengarahkan seperti apa perencanaan karir yang sesuai dengan faktor internal dan eksternal dari klien.

\section{Simpulan}

Teori Krumboltz beranggapan bahwa masing-masing individu memiliki empat faktor yang menyebabkan arah perencanaan karir. Dengan merencanakan arah karir dengan baik maka klien akan bisa membayangkan apa kemungkinan yang harus ia lakukan untuk mencapai karir tersebut dan bagaimana ia bisa mewujudkan perencanaan karirnya. Krumboltz menyatakan empat faktor yang mempengaruhi pengambilan keputusan karir yaitu warisan genetik dan kemampuan khusus seorang individu, peristiwa lingkungan atau bagaimana lingkungan terhadap individu tersebut, pengalaman belajar seorang individu dan keterampilan menghadapi tugas. Keseluruhan faktor ini akan saling bersinergi dalam diri individu sehingga ia merencanakan arah pilihan karir dengan baik. Dan bimbingan konseling berupaya untuk mengarahkan klien untuk menyinkronkan empat faktor ini dengan baik.

\section{Refrensi}

Abdullah, S. M. (2018). A Multiple Loops Career Crafting Model: Konstruksi Karier Di Era Boundaryless Workplace. Universitas Gajah Mada.

Aminurrohim, Ardiyatna Wahyu. Sinta Saraswati, Kusnarto Kurniawan. Survei Faktor-Faktor Pneghambat Perencanaan Karir Siswa. Indonesian Journal Of Guidance and Counseling Theory And Application. IJGC 3 (2) (2014). P. 57-63

Anisa, Siti. Sugiyo \& Catharina Tri Anni, Pengembangan Model Bimbingan Karir Terintegrasi Dalam Mata Pelajaran Bahasa Indonesia Untuk Meningkatkan Kesadaran Karir Siswa Sekolah Dasar, Jurnal Bimbingan Konseling 5 (2) (2016), p. 107-112

Hadiarni \& irman.(2009). Konseling Karier. Batusangkar: STAIN Batusangkar Press

Jannah, Miftahul. Tugas-Tugas Perkembangan Pada Usia Kanak-Kanak, Gender Equality: Internasional Journal of Child and Gender Studies, Vol. 1, No. 2, September 2015, p.87-98

Khairun, Deasy Yunika, Melly Sri Sulastri, Anne Hafina. Layanan Bimbingan Karir Dalam Peningkatan Kematangan Eksplorasi Karir Siswa. Jurnal Penelitian Bimbingan Dan Konseling. Vol 1 No 1, p. 123 
Mardiyati, B. D., \& Yuniawati, R. (2015). Perbedaan Adaptabilitas Karir Ditinjau Dari Jenis Sekolah (SMA Dan SMK). Empathy, 3(1), 31-41.

Mitchell, L.K. and Krumboltz, J.D. (1996). Krumboltz's learning theory of career choice and counseling. In D.Brown, L.Brooks and Associates (Eds). Career Choice and Development. 3rd edition. San Francisco: 3rd edition

Mitchell, A.M.., Jones, G.B. and Krumboltz, J.D.(Eds) (1979). Social Learning And Career DecisionMaking. Cranston, RI: Carroll Press

Sastrawati, Wayan Udayani. Ni Kadek Chandra Purwanti, Kadek Suhardita, I Ketut Sapta \& Ni Komang Sri Yuliastini. Efektivitas Konseling Behavioral Model Krumboltz Untuk Mengembangkan Keputusan Karir Siswa. Jurnal Konseling Indonesia http://ejournal.unikama.ac.id/index.php/JKI ISSN: Print 2475-888X - Online 2476-8901 Vol. 4 No. 2, April 2019. hlm. $63-67$

Sumita, Luhur Wicaksono, Yuline. Analisis Pemahaman Perencanaan Karir Siswa Di Kelas XII SMA Negeri 9 Pontianak. Jurnal pendidikan dan pembelajaran Khatulistiwa, Vol 7 No 7 (2018), p. 1-10

Yusuf, A. Muri. (2002). Kiat Sukses Dalam Karir, Padang: Ghalia Indonesia

Warsita, B. (2018). Teori Belajar Robert M. Gagne dan Implikasinya pada Pentingnya Pusat Sumber Belajar. Jurnal Teknodik, 12(1), 64-78.

Winkel WS \& MM. Sri Hastuti, 2007. Bimbingan Dan Konseling Di Institusi Pendidikan. Yogyakarta; Media Abadi

Zunker, Vernon G. 2006. Career Counseling A Holistic Approach. USA: Thomson Higher Education 10 Davis Drive Belmont, CA 94002-3098

Copyrights Holder: < Azmatul Khairiah Sari $><2021>$

https://doi.org/10.xxxx/xxxxx

Open Access Article | CC-BY Creative Commons Attribution 4.0 International License.

Word Count:

\section{Conflict of Interest Disclosures:}

The authors declare that they have no significant competing financial, professional or personal interests that might have influenced the performance or presentation of the work described in this manuscript.

First Publication Right: JIBK Undiksha 